\title{
Influence of Storage Humidity on Hardness of Light-cured Glass Polyalkenoate Cements
}

\author{
Shozo TSURUTA and Joachim VIOHL ${ }^{1}$ \\ Department of Dental Material Science, School of Dentistry, Aichi-Gakuin University, \\ 1-100, Kusumoto-cho, Chikusa-ku, Nagoya 464, Japan \\ 'Department of Dental Materials, School of Dentistry, Free University Berlin, \\ 4-6, A Bmannshauser Str., Berlin 14197, Germany
}

Received January 29, 1996/Accepted April 18, 1996

\begin{abstract}
The influence of storage in various environments on the hardness of four commercial light-cured glass polyalkenoate cements and one conventional glass polyalkenoate cement was investigated. Specimens with or without light exposure were stored for 7 days in different humidity conditions. A hardness tester with a diamond indenter point was used and Vickers hardness numbers under minor load conditions were determined. Non-light-exposed specimens did not increase in hardness in either dry or wet conditions. Lightexposed specimens became harder with time in dry conditions. Light-exposed specimens stored in wet conditions hardened only slightly. To investigate the effects of humidity, some light-exposed specimens stored first in wet conditions were stored another 7 days in dry conditions. They became as hard as those first stored in dry conditions for 7 days. It is concluded that the hardness of these cements corresponds with the humidity of the storage environment.
\end{abstract}

Key words: Glass polyalkenoate cement, Vickers hardness, Immersion test

\section{INTRODUCTION}

The primary setting reactions of conventional glass polyalkenoate cements are an acid-base and a sol-gel reaction ${ }^{1-3)}$. The mechanical properties of these cements change with time as the reactions continue ${ }^{4-8)}$. Visible light-cured glass polyalkenoate cements contains light -curing resin systems, generally 2-HEMA and camphorquinone ${ }^{9,10)}$. Light-curing polymerization is incorporated into the conventional setting system ${ }^{9)}$. According to manufacturers, light curing allows quick stabilization of the material, greatly reducing water sensitivity during early setting. Many investigations of mechanical properties of these cements have been carried out with storage in water to simulate conditions in the oral cavity ${ }^{5-7,11)}$. In recent years, however, glass polyalkenoate cements for fillings have come into wide use in clinical applications. Fillings are located dispersively and encounter different humidities in the oral cavity. In this study, we focused on the influence of storage conditions, especially humidity, on the cement's mechanical properties. The hardnesses of the surfaces under different preparation conditions, namely different light-curing and storage humidity conditions, were determined.

\section{MATERIALS AND METHODS}

Table 1 shows the name, manufacturer, lot, mixing time, and exposure time of the investigat- 
ed cements. FIIL and VLC are cements for fillings. FLC and VTB are for liner/base. $\mathrm{KFA}$ is a conventional non-light-cured glass polyalkenoate cement for fillings.

A cylindrical plastic mold (diameter $7 \mathrm{~mm}$, height $1.5 \mathrm{~mm}$ ) was placed between a mixing paper and a microscopic glass slide with a transparent polyester film. The mold was filled with mixed cement and then exposed through the polyester film with the visible light curing device*. Non-light-exposed specimens were also prepared.

The specimens were removed from the mold at 3 minutes after the start of mixing. They were stored in shaded light at $36 \% \mathrm{RH}$ (relative humidity) at $37^{\circ} \mathrm{C}, 100 \% \mathrm{RH}$ at $37^{\circ} \mathrm{C}$, distilled water at $37^{\circ} \mathrm{C}$, and $50 \% \mathrm{RH}$ at $23^{\circ} \mathrm{C}$. Non-light-exposed specimens were also stored at $36 \% \mathrm{RH}$ at $37^{\circ} \mathrm{C}$ and $100 \% \mathrm{RH}$ at $37^{\circ} \mathrm{C}$. Vickers hardness numbers under a load of $300 \mathrm{~g}$ were determined with a hardness tester** at periods from 20 minutes to 7 days.

The hardness tester in this study allowed the indentation to be observed through the diamond indenter point while under load. With a conventional hardness tester, the indentation recovers after releasing the load on viscoelastic materials such as resin, thus providing a reading in excess of the true hardness ${ }^{12}$. In contrast, the device used here has many advantages for testing cements, including resin systems: It does not matter whether the material is viscoelastic or not, because the load is not removed; the interface between the indenter and the specimen is clearly distinguished, readily to observe the small indentation on the resin or the ceramic with high light transmittance; the specimen can be continuously tested without breaking because of the small indentation and light load ${ }^{13)}$. When the indentation diameter was greater than $300 \mu \mathrm{m}$, the load was reduced to $50 \mathrm{~g}$ or $100 \mathrm{~g}$. The averages and standard deviations were obtained from 15 indentations on three specimens of each condition.

Some specimens were placed in different storage conditions after 7 days. Fig. 1 shows a flow chart of the experimental procedure. The specimens stored first at $36 \% \mathrm{RH}$ at $37^{\circ} \mathrm{C}$ were subsequently stored in water at $37^{\circ} \mathrm{C}$ for another 7 days. The specimens stored first at $100 \% \mathrm{RH}$ and in water at $37^{\circ} \mathrm{C}$ were then stored at $36 \% \mathrm{RH}$ at $37^{\circ} \mathrm{C}$ for 7 more days.

Table 1 Materials used.

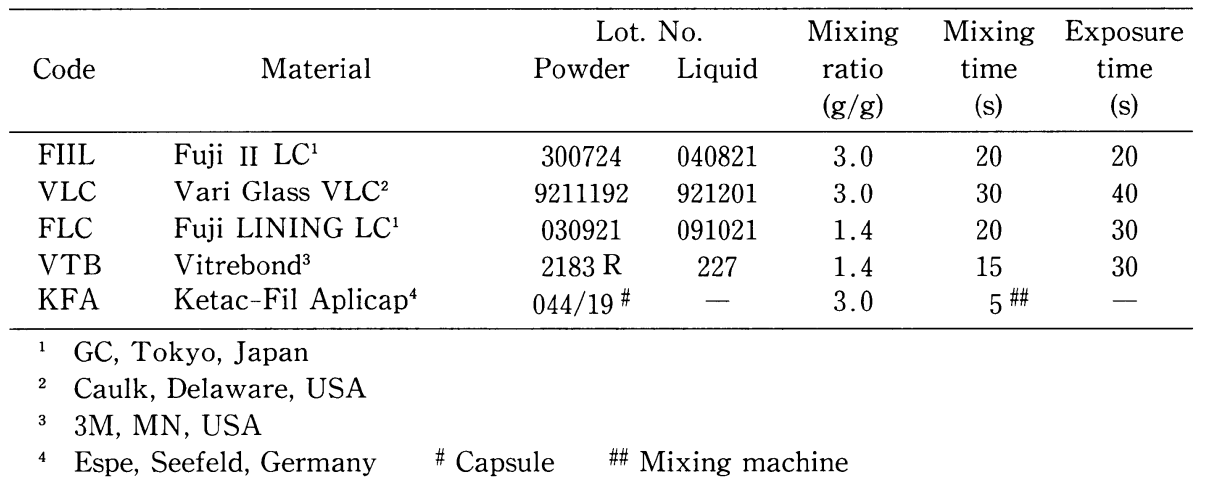

* Translux CL, Kulzer GmbH, Wehrheim, Germany

** Optidur, Göttfert GmbH, Buchen, Germany 


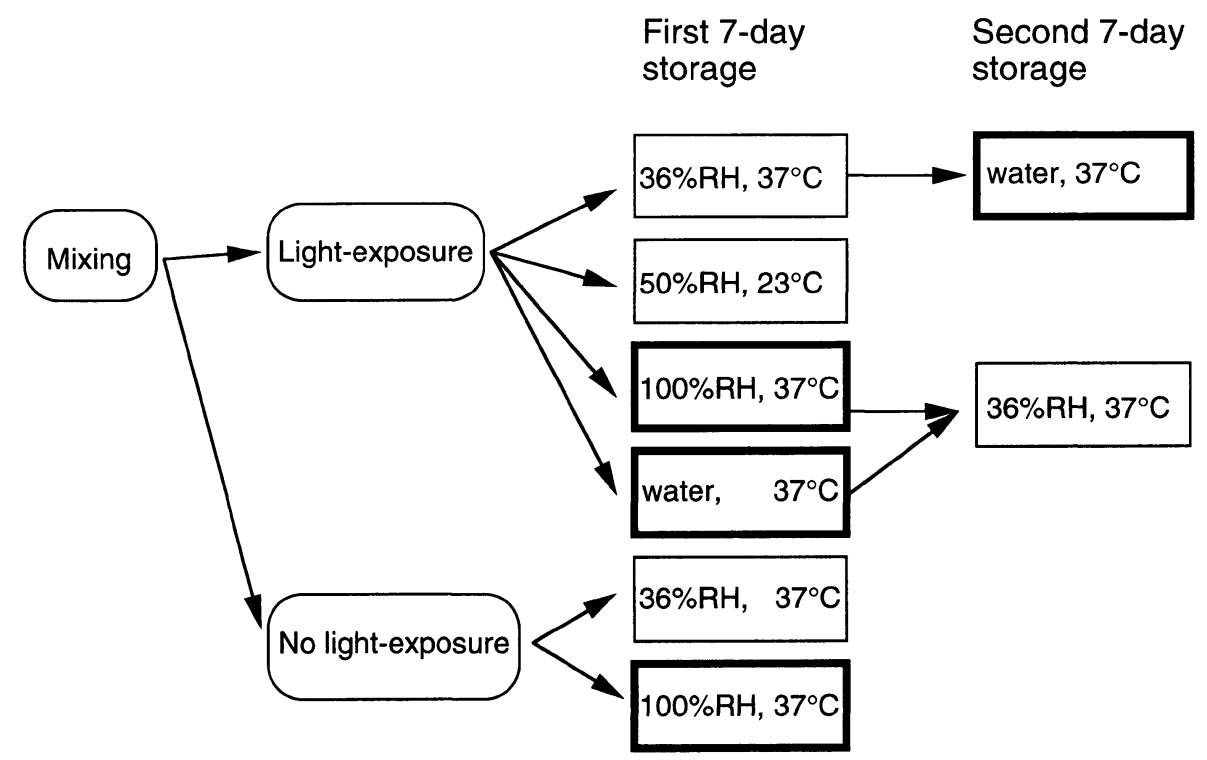

Fig. 1 Flow diagram of experimental procedure.

The narrow-lined squares represent dry conditions and the broad-lined squares represent wet conditions.

Hardnesses were then determined, and the student's t-test was used to test for significant differences between means.

\section{RESULTS AND DISCUSSION}

When the conventional hardness tester is used with viscoelastic materials, the indentation recovers and becomes smaller after the load is removed. Thus the Brinell hardness that is measured by the depth of indentation, the Knoop hardness that uses a long diagonal line, and the Vickers hardness with a major load are often used to correct for this effect. With the tester used in this study, on the other hand, the hardness is easily observed under a minor load. The diameters of the indentations in this study were 100 to $300 \mu \mathrm{m}$. This corresponds to indentation depths of 14 to $43 \mu \mathrm{m}$. The real surface hardness can also be determined this way. This surface hardness correlates with degradation in the oral cavity caused by friction against food or an opposing tooth cusp. The Vickers hardness is an appropriate parameter for comparison with other filling materials that are classified with Vickers hardness numbers in many standards. The surface hardness cannot be measured under a major load, but this study's hardness tester may be used to determine the hardness of glass polyalkenoate cement.

Figs. 2, 3 and 4 show the hardness curves over time for 7 days. For VLC, non-lightexposed specimens were not prepared because this cement needs light to set. KFA is a conventional cement, and all specimens were non-light-exposed. Non-light-exposed specimens of FIIL, FLC, and VTB did not quite set in either dry or wet conditions; it is indispens- 
able for these cements to be cured by light rediation.

Many reports ${ }^{4-11)}$ have shown that the increase of hardness on aging indicates a continuation of the reaction after exposure to the curing light. A similar pattern was seen in this study. The specimens in dry conditions, in particular, became harder than those in wet conditions upon continued storage. The hardnesses of these cements were determined by storage condition, $i$. e . humidity. Siliceous gels are precipitated around glass particles during setting in conventional glass polyalkenoate cement ${ }^{1,14)}$. It has been reported that this difference in mechanical behavior between dry and wet conditions is typical of hydrogels ${ }^{15,16)}$
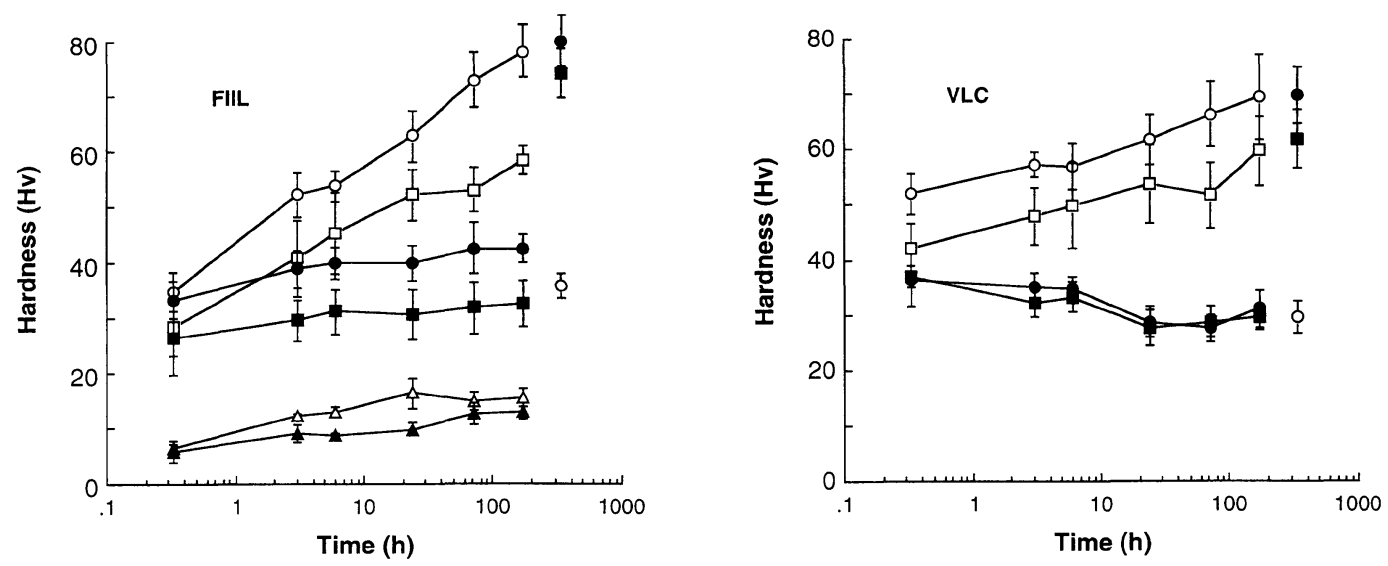

Fig. 2 Hardness change curves of filling cements on aging in various storage conditions.

$-\mathrm{O}^{-}: 36 \% \mathrm{RH}$ at $37^{\circ} \mathrm{C},-\square-: 50 \%$ at $\mathrm{RH} 23^{\circ} \mathrm{C},-\mathbf{-}^{-}: 100 \% \mathrm{RH}$ at $37^{\circ} \mathrm{C},-\square-:$ water at $37^{\circ} \mathrm{C},-\triangle^{-}$: without light exposure at $36 \% \mathrm{RH}$ at $37^{\circ} \mathrm{C},-\mathbf{\Delta}-$ : without light exposure at $100 \% \mathrm{RH}$ at $37^{\circ} \mathrm{C}$.

At seven days $(168 \mathrm{~h})$, the specimens which were stored at $36 \% \mathrm{RH}$ at $37^{\circ} \mathrm{C}$ were placed in water at $37^{\circ} \mathrm{C}$, and the specimens which were stored at $100 \% \mathrm{RH}$ at $37^{\circ} \mathrm{C}$ and in water at $37^{\circ} \mathrm{C}$ were changed to $36 \% \mathrm{RH}$ at $37^{\circ} \mathrm{C}$ for another seven days.
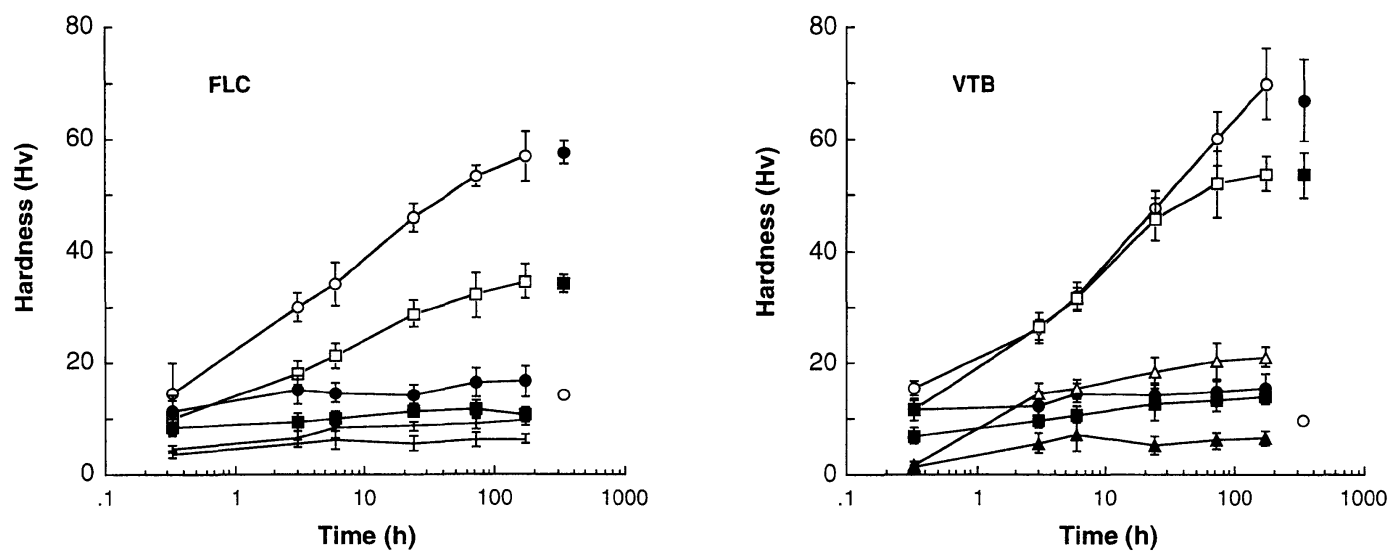

Fig. 3 Hardness change curves of liner/base cements on aging in various storage conditions. See Fig. 2 for legend. 
To investigate the effect of humidity, some specimens were placed in different storage conditions after 7 days. Table 2 and Figs. 2-4 show the hardness changes during the second

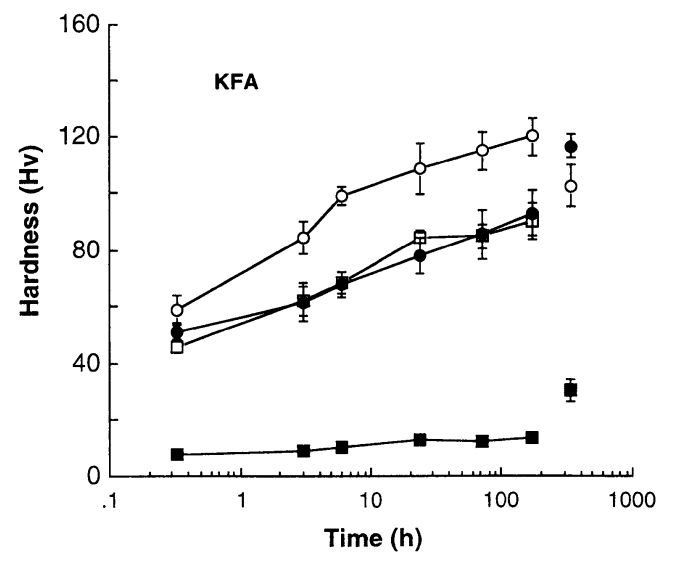

Fig. 4 Hardness change curves of the conventional cement on aging in various storage conditions.

See Fig. 2 for legend.

Table 2 Hardness by change of storage condition (HV, Mean(SD)).

\begin{tabular}{|c|c|c|c|}
\hline Code & Dry & Water & Change \% \\
\hline FIIL & $77.93(4.39)^{\mathrm{a}, \mathrm{b}}$ & $35.67(2.10)^{c}$ & -54.23 \\
\hline VLC & $69.40(7.77)^{\mathrm{A}, \mathrm{d}, \mathrm{e}}$ & $29.66 \quad(2.91)^{f, g}$ & -57.26 \\
\hline FLC & $56.79(4.43)^{1}$ & $14.13(0.64)^{\mathrm{j}}$ & -75.12 \\
\hline VTB & $69.87(6.40)^{\mathrm{A}, \mathrm{k}}$ & $9.567(0.620)$ & -86.31 \\
\hline \multirow[t]{2}{*}{$\mathrm{KFA}$} & $120.1(6.7)^{\mathrm{m}}$ & $102.2(7.4)^{\mathrm{n}, \mathrm{o}}$ & -14.90 \\
\hline & Wet & Dry & \\
\hline FIIL & $42.51(2.59)$ & $80.01 \quad(4.49)^{\mathrm{a}}$ & 88.21 \\
\hline VLC & $31.06(3.27)^{\mathrm{f}, \mathrm{h}}$ & $69.79(5.16)^{\mathrm{C}, \mathrm{d}}$ & 124.7 \\
\hline FLC & $16.58(2.62)^{\mathrm{B}, \mathrm{j}}$ & $57.63 \quad(1.99)^{1}$ & 247.6 \\
\hline VTB & $15.38(2.70)^{\mathrm{B}, 1}$ & $66.98(7.18)^{\mathrm{C}, \mathrm{k}}$ & 335.5 \\
\hline \multirow[t]{2}{*}{$\mathrm{KFA}$} & $92.61(8.08)^{n}$ & $116.5 \quad(4.1)^{\mathrm{m}, \mathrm{o}}$ & 25.80 \\
\hline & Water & Dry & \\
\hline FIIL & $32.40(4.28)^{\mathrm{D}, \mathrm{c}}$ & $74.31(4.47)^{\mathrm{b}}$ & 129.4 \\
\hline VLC & $29.56(1.15)^{\mathrm{D}, \mathrm{g}, \mathrm{h}}$ & $61.82(5.42)^{\mathrm{e}}$ & 109.1 \\
\hline FLC & $10.47(1.26)$ & $34.02(1.72)^{\mathrm{F}}$ & 224.9 \\
\hline VTB & $13.96(1.28)^{\mathrm{E}, \mathrm{I}}$ & $53.57 \quad(4.02)$ & 283.7 \\
\hline KFA & $13.51(1.28)^{\mathrm{E}}$ & $30.22(4.03)^{\mathrm{F}}$ & 123.7 \\
\hline
\end{tabular}

Mean values designated with the same superscript letter are not statistically different at $\mathrm{p}<$ 0.05 .

Uppercase letters indicate no difference within conditions per test ; lowercase letters indicate no difference within materials.

Dry : $36 \% \mathrm{RH}$ at $37^{\circ} \mathrm{C}$, Water : in water at $37^{\circ} \mathrm{C}$, Wet : $100 \% \mathrm{RH}$ at $37^{\circ} \mathrm{C}$. 
7 days. The hardness of the specimens stored first at $100 \% \mathrm{RH}$ increased in dry conditions. The hardness of the specimens stored first in dry conditions decreased in water. It is concluded that the hardness of these cements is related to the humidity of the storage conditions.

The specimens stored first in water did not harden further, unlike those stored first at $100 \% \mathrm{RH}$. Fluoride release from light-cured glass polyalkenoate cement has reported to equal that of conventional cements ${ }^{11,17-19)}$, and uptake of water has been observed ${ }^{19,20)}$. It is reported that the acid-base reaction is delayed after light exposure ${ }^{10)}$, and the unreacted $\mathrm{Al}$ and $\mathrm{Na}$ ions dissolve into the water ${ }^{21}$. This dissolution of elements prevented an increase in hardness by further storage in dry conditions. KFA showed the smallest hardness after initial storage in water followed by $36 \% \mathrm{RH}$. It is clear that light-cured cements are not as severely influenced by storage in water as are conventional cements.

The water sorption values $\left(\mu \mathrm{g} / \mathrm{mm}^{3}(\mathrm{SD})\right)$ of cements after 7 days were: FIIL $(140(8))$, VLC (85(4)), FLC (249(9)), and VTB (255(12)) ${ }^{22)}$. FLC and VTB exhibited high water sorption. The hardness of these speciments in water was much lower than at $36 \% \mathrm{RH}$. It is suspected that these cements in water showed so little hardness that the water was allowed to swell them and act as a plasticizer ${ }^{23,24)}$. Wilson et $a l .{ }^{5}{ }^{5}$ reported that the strength of dental cements as directly related to the ratio of "non-evaporable" to "evaporable" water. This observation is in agreement with their results. We conclude that these light-cured cements show the same behavior with respect to their water content as conventional cements.

Changes in mechanical properties caused by varied water content may take place in the oral cavity, as in the case of a mouth breather. This may hasten the degradation of cements ; cement fillings should thus be carefully observed over time in clinical usage.

\section{CONCLUSION}

In this study, we determined Vickers hardness numbers of four light-cured glass polyalkenoate cements in various storage conditions. The hardness of the specimens increased with time in dry conditions. The hardness of cements stored in high humidity and in water did not increase. The hardness of cements stored in dry conditions after initial storage in wet conditions increased, but cements stored in water after storage in dry conditions decreased in hardness. It is clear that the hardness of cements is controlled by the humidity of the storage condition. Fillings using these materials, as well as conventional glass polyalkenoate cements, should be carefully observed in clinical usage.

\section{ACKNOWLEDGMENT}

The authors would like to express their gratitude to the staff of the Department of Dental Materials, School of Dentistry, Free University Berlin (Dr. C. Frenzel, Dr. G. Schulz, Dr. R. Strietzel, and Dr. G. Wimmer) for their advice concerning this study. 


\section{REFERENCES}

1) Crisp, S., Pringuer, M. A., Wardleworth, D. and Wilson, A. D. : Reactions in glass ionomer cements : II. An infrared spectroscopic study, J Dent Res 53 (6) : 1414-1419, 1974.

2) Crisp, S. and Wilson, A. D. : Reactions in glass ionomer cements: III. The precipitation reaction, $J$ Dent Res 53 (6) : 1420-1424, 1974.

3) Barry, T. I., Clinton, D. J. and Wilson, A. D.: The structure of a glass-ionomer cement and its relationship to the setting process, J Dent Res 58 (3), 1072-1079, 1979.

4) Crisp, S., Lewis, B. G. and Wilson, A. D. : Characterization of glass-ionomer cements 1. Long term hardness and compressive strength, J Dent 4 (4), 162-166, 1976.

5) Wilson, A. D., Paddon, J. M. and Crisp, S. : The hydration of dental cements, J Dent Res 58 (3), 10651071, 1979.

6) McCaghren, R. A., Retief, D. H., Bladley, E. L. and Denys, F. R. : Shear bond strength of light-cured glass ionomer to enamel and dentin, J Dent Res 69 (1): 40-45, 1990.

7) Bourke, A. M., Walls, A. W. and McCabe, J. F.: Light-activated glass polyalkenoate (ionomer) cements : the setting reaction, J Dent 20 (2) : 115-120, 1992.

8) Soltesz, U. and Leupolz, M.: Härte-und Festigkeitsverhalten von Glasionomerzementen, Dtsch Zahaerztl Z 48 (4) : 237-241, 1993.

9) Mitra, S. B. : Adhesion to dentin and physical properties of a light-cured glass-ionomer liner/base, $J$ Dent Res 70 (1) 72-74, 1991.

10) Eliades, G. and Palaghias, G. : In vitro characterization of visible light-cured glass ionomer liners, Dent Mater 9 (3) : 198-203, 1993.

11) Mitra, S. B. : In vitro fluoride release from a light-cured glass-ionomer liner/base, $J$ Dent Res 70 (1) : 75-78, 1991.

12) Pommer, D. and Viohl, J. : Vergleichende Härtemessungen and Verblendkunststoffen, Dtsch Zahaerztl Z 43 (10): 1048-1050, 1988.

13) Tsuruta, S. and Viohl, J.: The effect of mixing ratio, mixing time and light curing time on hardness of a light-cured polyalkenoate cement, Aichi-Gakuin J Dent Sci 33 (3): 607-610, 1995. (in Japanese)

14) Hatton, P. V. and Brook, I. M.: Characterization of the ultrastructure of glass-ionomer (polyalkenoate) cement, Brit Dent J 173 (7) : 275-277, 1992.

15) Nicholson, J. W., Anstice, H. M. and Mclean, J. W. : A preliminary report on the effect of storage in water on the properties of commercial light-cured glass-ionomer cements, Brit Dent J 173 (8) : 98-101, 1992.

16) Anstice, H. M. and Nicholson, J. W. : Studies on the structure of light-cured glass-ionomer cements, J Mater Sci Mater Med 3: 447-451, 1992.

17) Tam, L. E., McComb, D. and Pulver, F.: Physical properties of proprietary light-cured lining materials, Oper Dent 16: 210-217, 1991.

18) Momoi, Y. and McCabe J. F.: Fluoride release from light-activated glass ionomer restorative cements, Dent Mater 9 (3) : 151-154, 1993.

19) Forss, F. : Release of fluoride and other elements from light-cured glass ionomers in neutral and acidic conditions, $J$ Dent Res 72 (8) : 1257-1262, 1993.

20) Irie, M. and Nakai, H. : Effect of immersion in water on linear expansion and strength of three base/ liner materials, Dent Mater J 14 (1) : 70-77, 1995.

21) Crisp, S., Lewis, B. G. and Wilson, A. D. : Characterization of glass-ionomer cements 6 . A study of erosion and water absorption in both neutral and acidic media, J Dent 8 (1), 68-74, 1980.

22) Schulz, G. and Viohl, J.: Personal communication, 1994.

23) Williams, B., von Fraunhofer, J. A. and Winter, G. B. : A comparative evaluation of the microhardness, water solubility and water absorption of fissure sealants, $J$ Dent 3 (1) : 1-8, 1975.

24) Cattani-Lorente, M-A., Godin, C. and Meyer, J-M. : Mechanical behavior of glass ionomer cements affected by long-term storage in water, Dent Mater 10 (1): 37-44, 1994. 


\title{
レジン系仮封材がレジンセメントの歯質接着強さに及ぼす影響
}

\author{
寺田林太郎, 吉中 晋, 中島 薫, 久保田稔 \\ 岩手医科大学歯学部歯科保存学第一講座
}

この研究は, レジン系仮封材がレジンセメントの歯質 接着強さに及ほす影響について, 400 本の牛歯を用い, 4 種レジン系仮封材と 4 種レジンセメントを使用して実験 を行ったものである. エナメル質では, いずれのレジン
系仮封材もレジンセメントの歯質接着強さを減少させて いなかった. 象牙質では, いずれのレジン系仮封材も 4 -META/MMA-TBB 系レジンセメントを除くレジン セメントの歯質接着強さを減少させていた。

\section{光重合型ポリアルケノエートセメントの硬さに及ぼす保存湿度の影響}

\section{鶴田 昌三, Joachim Viohl ${ }^{1}$}

愛知学院大学歯学部歯科理工学講座

${ }^{1}$ Department of Dental Materials, School of Dentistry, Free University Berlin

4 種の市販光重合型グラスポリアルケノエートセメン トと 1 種の従来型グラスポリアルケノエートセメントの 硬さに及ほすす保存環境の影響を検討した.このため光照 射有りまたは無しの試料を異なる湿度の環境下で 7 日間 保存した.ダイヤモンド压子を通して压痕を観察できる 硬さ試験機を用いて低荷重を負荷した状態でのビッカー ス硬さを測定した. その結果光照射無しの試料は乾燥と 湿潤環境下で硬さは増加しなかった. 光照射有りの試料
は乾燥環境下で経時的に硬くなったが,湿潤環境下では ほとんど増加しなかった，湿度の影響をさらに検討する ため，最初湿潤環境に保存した試料をさらに続いて 7 日 間乾燥環境に保存した。保存後セメントは乾燥環境に最 初 7 日間保存した試料と同程度まで硬くなった。した がって本セメントの硬さは保存環境の湿度に関係してい ると考えられる. 